\title{
Evaluation of lambdacyhalothrin, deltamethrin and permethrin against filth flies (Diptera: Muscidae, Calliphoridae) at a garbage dumping ground and a poultry farm in Malaysia
}

\author{
Sallehudin Sulaiman, Baharudin Omar, Sulaiman Omar, \\ John JEFFERY and Ismail GHAUTH \\ Department of Parasitology and Medical Entomology, Faculty of Medicine, \\ National University of Malaysia, Jalan Raja Muda Abdul Aziz, \\ 50300 Kuala Lumpur, Malaysia
}

(Received: May 7, 1991)

Key words: insecta, insecticides, housefly, garbage dumping ground, poultry farm.

\begin{abstract}
The pyrethroids lambdacyhalothrin, deltamethrin and permethrin were evaluated against field populations of housefly Musca domestica L. and blowfly Chrysomya megacephala (Fabricius) in a garbage dumping ground and a poultry farm. Lambdacyhalothrin and deltamethrin were more effective compared to permethrin during evaluation at a garbage dumping ground, causing high percentage of fly larval knockdown at $1 \mathrm{hr}$ and larval mortality $24 \mathrm{hr}$ after spraying. Applications at a poultry farm showed that all three pyrethroids were equally effective against fly larvae, $1 \mathrm{hr}$ after spraying and lambdacyhalothrin was the most effective insecticide $24 \mathrm{hr}$ after spraying.
\end{abstract}

\section{INTRODUCTION}

The potentials of housefly Musca domestica L. and blowfly Chrysomya megacephala (Fabricius) in transmitting pathogenic organisms such as protozoan cysts, helminth eggs and larvae, bacteriae and enteroviruses to food which would later be consumed by man are well documented (Reid, 1953; Greenberg, 1973; Sulaiman et al., 1988a, b, 1989). Both fly species are among the major pests of public health importance in Malaysia and South-East Asian countries and control of these species depends largely on utilization of insecticides.

The objective of this study is to evaluate the pyrethroids lambdacyhalothrin (Icon), deltamethrin (Cislin) and permethrin (Perigen) against fly populations in the field in
Malaysia. The insecticides were tested against a mixed populations of $M$. domestica and $C$. megacephala at a garbage dumping ground and a poultry farm.

\section{Materials and Methods}

Insecticides evaluation against housefly and blowfly at a garbage dumping ground in Lukut, Port Dickson. The garbage dumping ground is located at Lukut, Port Dickson, about $115 \mathrm{~km}$ to the south of Kuala Lumpur. It had an area of 2 ha. Rubbish originating from households, hotels and shops was trucked and dumped in this area daily. Four plots where flies were breeding in abundance were selected for this experiment. Each plot had an area of $10 \times 10 \mathrm{~m}$. Three plots were individually sprayed with a specific insecticide using a hand-operated knapsack sprayer 
(CP15-manufactured by Cooper, Pegler \& Co. Ltd., Sussex, England) and the fourth plot as a control was sprayed with an equal amount of water. Three insecticides, namely, Icon ${ }^{\circledR}$ EC containing lambdacyhalothrin $2.5 \% \mathrm{w} / \mathrm{v}$, Cislin ${ }^{\circledR}$ EC containing deltamethrin $2.5 \% \mathrm{w} / \mathrm{v}$ and Perigen ${ }^{\circledR}$ containing permethrin $10 \% \mathrm{w} / \mathrm{v}$ were evaluated against both fly species at a dose of $0.01 \mathrm{~g}$ active ingredient $/ \mathrm{m}^{2}$ ( $=\mathrm{a}$ total of $1 \mathrm{~g}$ active ingredient in $5 l$ of water for each insecticide). The plot for a specific insecticide was selected at random and the field experiment was repeated four times.

Larval sampling: Larval sampling was conducted using a wooden square with an inside opening of $30.48 \times 30.48 \mathrm{~cm}$. Ten samples each were taken from every plot randomly before spraying, and at 1 and $24 \mathrm{hr}$ after spraying and the numbers of dead and live larvae were noted. The populations of both $M$. domestica and $C$. megacephala larvae during each sampling were pooled together.

Adult sampling: Adult sampling was carried out on each plot using the Scudder grill which is a series of $2.5 \mathrm{~cm}$ wooden slabs fixed $2.5 \mathrm{~cm}$ apart on a wooden frame to make a $45 \mathrm{~cm}$ square grill. The duration for each sampling was standardized at $1 \mathrm{~min}$ and the number of adult flies resting was counted. Ten samples each were taken randomly from every plot before spraying and at 1 and $24 \mathrm{hr}$ after spraying. As in the case of the larvae, the numbers recorded for both species of adult flies were pooled together for each sampling. The data was analyzed by ANOVA and Least Significant Difference test (Choi, 1978).

Evaluation of insecticides against housefly and blowfly at Ceras poultry farm. The chicken farm was located about $18 \mathrm{~km}$ from Kuala Lumpur and the chickens were raised in rows of wire cages about $1 \mathrm{~m}$ above the ground. The droppings were usually removed from the concrete floor once every 2 weeks.

Four plots, each measuring $8 \times 12.5 \mathrm{~m}$, were chosen from one of the rows of chicken cages. Selection of the specific insecticide to be sprayed to each plot was made at random. Larval and adult samplings of the flies were conducted according to the method in experiment I. Analysis of variance was performed using the ANOVA and LSD test
(Choi, 1978).

\section{Results and Discussion}

Field evaluation of the three pyrethroids on mortality of fly larvae in a garbage dumping ground at Lukut, Port Dickson, after $1 \mathrm{hr}$ spraying showed that deltamethrin, lambdacyhalothrin and permethrin had caused a mean knockdown of 42.2, 27.6 and $10.7 \%$, respectively, compared to $2.1 \%$ knockdown in the control plot (Table 1a). Thus, deltamethrin was more effective than permethrin (LSD, $p<0.01$ ) but not significantly different from lambdacyhalothrin at $1 \mathrm{hr}$ after spraying (Table 1a). However, at $24 \mathrm{hr}$ after spraying lambdacyhalothrin was the most effective insecticide causing $51.0 \%$ larval mortality compared to deltamethrin, permethrin and control with $41.7,22.7$ and $5.2 \%$ larval mortality, respectively. Thus, lambdacyhalothrin was more effective than permethrin (LSD, $p<0.01)$ and control (LSD, $p<0.0005$ ) but not significantly different from deltamethrin (LSD, $p>0.05$ ) (Table 1b).

On field evaluation of the three pyrethroids against fly larvae at the Ceras poultry

Table 1a The knockdown of fly larvae, $1 \mathrm{hr}$ after spraying at Port Dickson garbage dumping ground.

\begin{tabular}{lccc}
\hline Insecticide & \multicolumn{1}{c}{$\begin{array}{c}\text { knockdown of } \\
\text { fly larvae }\end{array}$} & $\begin{array}{c}\text { Mean } \\
(\%)\end{array}$ \\
\hline Lambdacyhalothrin & $\begin{array}{l}20.3,12.1,15.5, \\
62.5\end{array}$ & 27.6 \\
& & & \\
Deltamethrin & $22.6,65.9,31.5$, & 42.2 \\
& 48.8 & & \\
& $11.2, \quad 9.8,15.9$, & 10.7 \\
Permethrin & 5.9 & & \\
& & & \\
Control & $0.0,0.2,0.0$ & 2.1 \\
& 8.3 & & \\
& &
\end{tabular}

There is significant difference among the means (ANOVA, $p<0.05$ ). There is significant difference between deltamethrin and permethrin (LSD, $p<0.01$ ), but no significant difference between deltamethrin and lambdacyhalothrin (LSD, $p>0.05$ ). 
Table 1b The mortality of fly larvae, $24 \mathrm{hr}$ after spraying at Port Dickson garbage dumping ground.

\begin{tabular}{|c|c|c|}
\hline Insecticide & $\begin{array}{l}\text { \% mortality of } \\
\text { fly larvae }\end{array}$ & $\underset{(\%)}{\operatorname{Mean}}$ \\
\hline Lambdacyhalothrin & $\begin{array}{l}74.8,30.2,38.3 \\
60.5\end{array}$ & 51.0 \\
\hline Deltamethrin & $\begin{array}{l}40.0,33.4,40.5 \\
52.7\end{array}$ & 41.7 \\
\hline Permethrin & $\begin{array}{l}8.6,16.5,28.4, \\
37.2\end{array}$ & 22.7 \\
\hline Control & $\begin{array}{rll}0.7, & 1.5, & 0.0 \\
18.4 & \end{array}$ & 5.2 \\
\hline
\end{tabular}

There is significant difference among the means (ANOVA, $p<0.05$ ). There is significant difference between lambdacyhalothrin and permethrin (LSD, $p<0.01$ ), but no significant difference between lambdacyhalothrin and deltamethrin (LSD, $p>0.05$ ).

farm, $1 \mathrm{hr}$ after spraying, lambdacyhalothrin, deltamethrin and permethrin resulted in 53.5, 58.3 and $50 \%$ mean knockdown, respectively, compared to that of control with $6.8 \%$ mean mortality of larvae (Table 2a). Lambdacyhalothrin and deltamethrin did not show significant difference in causing larval knockdown of flies at $1 \mathrm{hr}$ after spraying, but lambdacyhalothrin was the most effective pyrethroid at $24 \mathrm{hr}$ after spraying compared to permethrin (LSD, $p<0.01$ ) and deltamethrin (LSD, $p<0.05$ ) (Tables $2 \mathrm{a}, 2 \mathrm{~b})$.
The results of insecticidal spraying of fly larvae $(M$. domestica and $C$. megacephala) in the field showed that lambdacyhalothrin and deltamethrin were effective in causing high mortality in an area exposed directly to sunlight such as in the garbage dumping ground at Lukut, Port Dickson, compared to permethrin. Our results are in contrast to that of Thomson (1989) which mentioned that permethrin has good residual activity since sunlight does not break it down rapidly.

At the Ceras poultry farm where the insecticides sprayed were not exposed directly to sunlight, all the three insecticides were effective in causing high larval knockdown at $1 \mathrm{hr}$ after treatment. However, at $24 \mathrm{hr}$ after spraying, lambdacyhalothrin was shown to be the most effective compared to deltamethrin and permethrin in causing mortality of $M$. domestica and C. megacephala larvae. The above findings indicated that lambdacyhalothrin could be a useful insecticide for controlling the larvae of filth flies in the field.

The efficacy of the pyrethroids in reducing the field population of adult flies was estimated based on the relative scudder grill counts. At the garbage dumping ground, Port Dickson, investigation $1 \mathrm{hr}$ after spraying indicated that lambdacyhalothrin, deltamethrin and permethrin had reduced the adult field population by $82.2,82.1$ and $75.2 \%$, respectively, compared to $28.3 \%$ reduction in the control plot. Thus, there was a significant difference between the pyrethroids and that of the control (ANOVA, $p<0.05$ ) (Table 1c). However, at $24 \mathrm{hr}$ after spraying there was no significant differ-

Table 1c Mean number of adult fly population at Port Dickson dumping ground sampled by Scudder grill per min (percentage reduction of fly population to that of before spraying in parenthesis).

\begin{tabular}{lccc}
\hline \multirow{2}{*}{ Insecticide } & \multicolumn{4}{c}{ Mean No. of adult flies } \\
\cline { 2 - 4 } & Before spraying & 1 hr after spraying & 24 hr after spraying \\
\hline Lambdacyhalothrin & 614 & $109(82.2 \%)$ & $143(76.7 \%)$ \\
Deltamethrin & 772 & $138(82.1 \%)$ & $135(82.5 \%)$ \\
Permethrin & 738 & $183(75.2 \%)$ & $304(58.8 \%)$ \\
Control & 1,247 & $894(28.3 \%)$ & $701(43.8 \%)$ \\
\hline
\end{tabular}

One hr after spraying there is significant difference among the population reduction means (ANOVA, $p<0.05$ ), but not after $24 \mathrm{hr}$ after spraying (ANOVA, $p>0.05$ ). 
Table 2a The knockdown of fly larvae $1 \mathrm{hr}$ after spraying at Ceras poultry farm.

\begin{tabular}{lcc}
\hline \multicolumn{1}{c}{ Insecticide } & $\begin{array}{c}\text { \% knockdown of } \\
\text { fly larvae }\end{array}$ & $\begin{array}{c}\text { Mean } \\
(\%)\end{array}$ \\
\hline Lambdacyhalothrin & $50.3,74.9,35.4$ & 53.5 \\
Deltamethrin & $55.9,61.9,57.1$ & 58.3 \\
Permethrin & $56.9,60.1,33.1$ & 50.0 \\
Control & $5.3,3.5,11.7$ & 6.8 \\
\hline
\end{tabular}

There is significant difference among the means (ANOVA, $p<0.01$ ). No significant difference between lambdacyhalothrin and deltamethrin (LSD, $p>0.05$ ). No significant difference between lambdacyhalothrin and permethrin (LSD, $p>0.05$ ).

Table $2 \mathrm{~b}$ The mortality of fly larvae $24 \mathrm{hr}$ after spraying at Ceras poultry farm.

\begin{tabular}{lrr}
\hline \multicolumn{1}{c}{ Insecticide } & $\begin{array}{c}\text { \% mortality of } \\
\text { fly larvae }\end{array}$ & $\begin{array}{c}\text { Mean } \\
(\%)\end{array}$ \\
\hline Lambdacyhalothrin & $39.1,71.0,74.1$ & 61.4 \\
Deltamethrin & $40.0,12.6,48.4$ & 33.7 \\
Permethrin & $2.7,24.7,36.6$ & 21.3 \\
Control & $8.8, \quad 0.2,12.8$ & 7.3 \\
\hline
\end{tabular}

There is significant difference among the means (ANOVA, $p<0.05$ ). There is significant difference between lambdacyhalothrin and deltamethrin (LSD, $p<0.05$ ). There is significant difference between lambdacyhalothrin and permethrin (LSD, $p<0.01)$.

ence among all treatments (including the control) (ANOVA, $p>0.05$ ) (Table 1c).

At the Ceras poultry farm, investigation $1 \mathrm{hr}$ after spraying indicated that between
78.2 and $81.4 \%$ of the adult fly population was reduced by the pyrethroids. Nevertheless, there was no significant difference among all treatments (ANOVA, $p>0.05$ ) (Table 2c). However, at $24 \mathrm{hr}$ after spraying, lambdacyhalothrin had showed the highest number of adult fly reduction with $77.9 \%$ followed by permethrin $(65.8 \%)$, deltamethrin $(56.2 \%)$ and control $(3.3 \%)$, respectively. Thus, there was a significant difference between the treatments (ANOVA, $p<0.01$ ) (Table 2c). The above results indicated that as a larvicide in an open space exposed to sunlight, lambdacyhalothrin and deltamethrin were more effective than permethrin. However, in sheltered areas such as the poultry farm lambdacyhalothrin was the most effective. As an adulticide applied at an open space under direct sunlight all the three pyrethroids were effective in reducing the adult population within a short period of $1 \mathrm{hr}$. However, at $24 \mathrm{hr}$ after treatment there was no significant difference among the pyrethroids although there were reductions in fly populations.

As mentioned earlier, both lambdacyhalothrin and deltamethrin were effective larvicides and further studies over a long period of time could be helpful in reducing the fly population in such study area. Studies at the sheltered poultry farm indicated lambdacyhalothrin was the most effective pyrethroid compared to deltamethrin and permethrin.

Both deltamethrin and permethrin have been recommended by WHO for residual treatment in fly control (WHO, 1984). The new pyrethroid lambdacyhalothrin seems to have the potential to be a vital element for

Table 2c Mean number of adult fly population at Ceras poultry farm sampled by Scudder grill per min (percentage reduction in parenthesis).

\begin{tabular}{lccc}
\hline \multirow{2}{*}{ Insecticide } & \multicolumn{4}{c}{ Mean No. of adult flies } \\
\cline { 2 - 4 } & Before spraying & 1 hr after spraying & 24 hr after spraying \\
\hline Lambdacyhalothrin & 331 & $62(81.3 \%)$ & $73(77.9 \%)$ \\
Deltamethrin & 450 & $98(78.2 \%)$ & $197(56.2 \%)$ \\
Permethrin & 354 & $66(81.4 \%)$ & $121(65.8 \%)$ \\
Control & 331 & $319(3.6 \%)$ & $320(3.3 \%)$ \\
\hline
\end{tabular}

There is no significant difference among the population reduction (ANOVA, $p>0.05$ ) $1 \mathrm{hr}$ after spraying, but there is significant difference $24 \mathrm{hr}$ after spraying (ANOVA, $p<0.01$ ). 
fly control in public health in the near future.

\section{AGKNOWLedGements}

We wish to thank the Ministry of Science Technology \& Environment, Malaysia for awarding the research grant IRPA 3-07-03-21 to support this study and the National University of Malaysia for research facilities. Last but not least, we wish to thank Mrs. Hanili Hadi for typing the manuscript.

\section{ReFERENGES}

Choi, S. C. (1978): Introductory Applied Statistics in Science, 278 pp., Prentice Hall, Inc., Eaglewood Cliffs, New Jersey.

Greenberg, B. (1973): Flies and Disease, Vol. II. Biology and Disease Transmission, 447 pp., Princeton University Press, New Jersey.

Reid, J. A. (1953): Notes on houseflies and blowflies in Malaya. Bull. Inst. Med. Res. Fed. Malaya, 7: 1-26.

Sulaiman, S., A. H. Aziz, H. Yunus and A. R. Sohadi (1988a): Isolations of enteropathogenic bacteria from some cyclorrhaphan flies in Malaysia. Malays. Appl. Biol., 17: 129-133.

Sulaiman, S., A. R. Sohadi and J. Jeffery (1989) : Human helminth parasite burdens on cyclorrhaphan flies (Diptera) trapped at an aboriginal settlement in Malaysia. Bull. Entomol. Res., 79:
625-629.

Sulaiman, S., A. R. Sohadi, H. Yunus and R. Iberahim (1988b): The role of some cyclorrhaphan flies as carriers of human helminths in Malaysia. Med. Vet. Entomol., 2: 1-6.

Thomson, W. T. (1989 revision): Agricultural Chemicals Book I Insecticides, Acaricides and Ovicides, 288 pp., Thomson Publications, Fresno, California.

WHO (1984): Chemical Methods for the Control of Arthropod Vectors and Pests of Public Health Importance, $108 \mathrm{pp}$,, World Health Organization, Geneva.

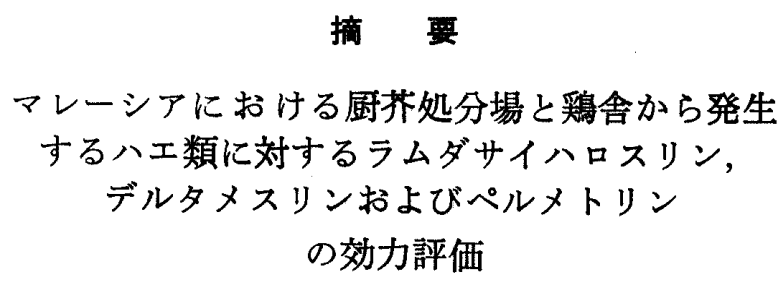

酎芥処分場と鶏舎から発生するイエバエとオビキン バエに対する， 3 種のピレスロイド威の効力を比較し た.ラムダサイハロスリンとデルタメスリンは欴芥処 分場では処理 1 時間後の八エ动虫のノックダウン率お よび24時閒後の八エ幼虫死亡率はペルメトリンよりも 共に高率であった. 鶏合においては 3 種のピレスロイ ドは処理 1 時間後のハエ幼虫ノックダウン率では同等 に効果的であったが，24時間後の八エ幼虫死亡率で見 た場合，ラムダサイハロスリンが最も有効であった。 